\title{
Charcoal and Fuelwood Consumption and Its Impacts on Environment in Cote d'Ivoire (Case Study of Yopougon Area)
}

\author{
Aboh Prisca Zidago ${ }^{1} \&$ Zhangqi Wang ${ }^{2}$ \\ ${ }^{1}$ China University of Geosciences, Wuhan, China \\ ${ }^{2}$ Department of Business administration, China University of Geosciences, China \\ Correspondence: Aboh Prisca Zidago, China University of Geosciences, Wuhan, China. E-mail: kpriss7@yahoo.fr
}

Received: May 1, 2016

Accepted: June 2, 2016

Online Published: October 17, 2016

doi:10.5539/enrr.v6n4p26

URL: http://dx.doi.org/10.5539/enrr.v6n4p26

\begin{abstract}
The difficulty in accessibility to energy by households in some regions is one of the major problems in World. This article described the use of some fuels such as charcoal fuel, and these different effects on consumers and producers in Abidjan of Cote d'Ivoire. A qualitative analysis through the households has showed that charcoal was the fuel most used in households and even the choice of its poor energies mainly socio economic. Moreover, the production and consumption have a negative impact on the health of producers and consumers. This research has shown that many users are unaware of the health hazards. This paper argues that to improve these situations require more coordinated and innovative plans and policies from the government. This paper suggests that greater emphasis will be needed in reducing dependence of biomass for cooking, promoting domestic alternative energy sources, and also presented a policy approach to minimize or eradicate health problems.
\end{abstract}

Keywords: environment, poor energy, households, health hazard, accessibility

\section{Introduction}

More than 2 billion people use wood, charcoal, dung or agricultural residues as the primary fuel for their cooking and heating needs, leading to significant health, economic and environmental consequences (WHO, 2010). Burning wood or agricultural residues produces smoke with a variety of irritant pollutants, some of which are known carcinogens. More than 1.5 million deaths a year are caused by acute respiratory infections from breathing smoke from indoor cooking fires. Women and children are generally exposed to the greatest levels of pollutants and it is children who suffer the greatest health risk. Respiratory infections are the leading cause of death of young children worldwide.

Biomass accounts for $73 \%$ of total domestic energy consumption (see Figure 1) and about $87 \%$ of households use firewood or charcoal with $2 \mathrm{~kg}$ of charcoal or $4.6 \mathrm{~kg}$ of firewood per day (Ministry of Housing, the living and the environment, 1997). More than half of the domestic energy needs are met by combustible renewable resources and waste, mainly in the form of biomass. It must also be noted that energy use depends upon their accessibility/availability as well as energy costs. Seen the poverty of developing countries and the price increase for petroleum products, firewood is still the most used fuel in rural areas, charcoal is mainly intended for large cities. For example, Abidjan $90 \%$ of population use the charcoal produces in the households (environmental department, 2000). Poverty conditions are also worsened through the health and quality of life impacts associated with traditional biomass fuels.

This article presented the problem of the use of charcoal and fuelwood by the population, the major problem of the consumption of these fuels is due to poverty. With the economic instability, has added in 1990, socio political instability since 1999 plunged the country into the worst crisis in its history culminating in the armed conflict in September 2002. Thus, the crisis has negative effects on the overall economic and social life. In GDP growth rate from $5.7 \%$ in 1998 , collapsed at $-1.8 \%$ in 2002 and the poverty rate was between 42 and $44 \%$ in 2003 with an increase in inequality of income between rich and poor. 


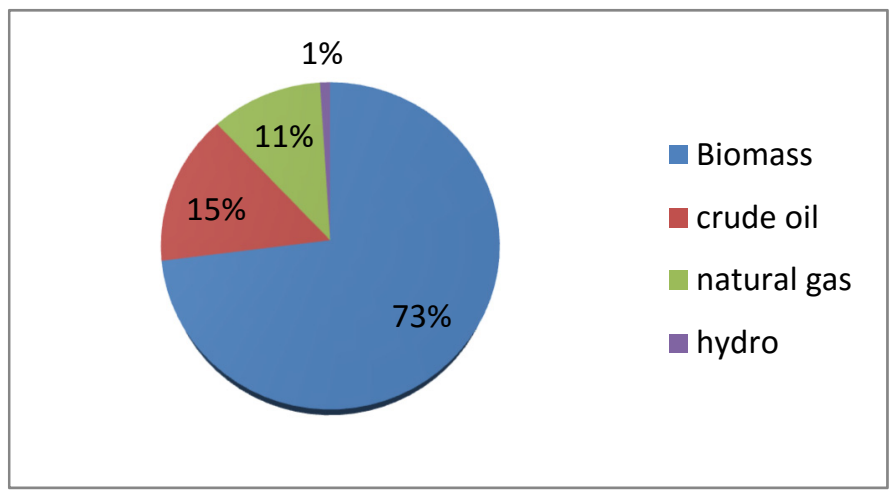

Figure 1. energy consumption in Cote d'Ivoire (IEA, 2014)

\section{Literature Review}

In the year 2000, indoor air pollution from solid fuel use was responsible for more than 1.6 million annual deaths and $2.7 \%$ of the global burden of disease (World Health Organization, 2000). Research on the relationship between environmental impact and household energy consumption has attracted considerable attention from researchers and analysts, who mainly concentrate on two aspects: the empirical estimation of energy demand functions and the impact effects on forest and children and women.

Solid fuel burning in the residential sector is a source of a variety of emissions including carbon monoxide, benzo[a]pyrene, formaldehyde, and nitrogen dioxide and particulate matter, with levels dependent upon the fuel types, combustion processes, and, of course, the scale of such solid fuel burning activities. (Clinch \& Healy, 2000a), but are also linked to severe adverse health outcomes including acute respiratory infections (ARI), chronic obstructive pulmonary disease (COPD) cancers, cataracts, and low birth weight for those exposed, and this has tangible implications for quality of life and health care costs (Clancy, Goodman, Sinclair, \& Dockery, 2002). However, it appears that young children in Africans households that use solid biomass fuels are 2 to 3 times more likely to suffer ARI than children in households that use other fuels (Smith \& Mehta, 2000). Similarly, women who have cooked over biomass fires for 15 years are 2 to 4 times more likely to develop COPD than are other women (Smith, 1999)

Among all of the energy sources considered, firewood has the highest budget share among its users. The urban poor in countries such as Nepal and Guatemala spend significant shares of their total expenditures on wood, around 5 percent when averaged over all households in the bottom quintile and around 10-15 percent when averaged over wood users only.

Globally, there is a lack of detailed statistics on fuelwood and charcoal consumption, their spatial distribution and future projections. This is due to several factors such as the fact that a large proportion of fuelwood is harvested and used in rural areas without entering the formal markets and statistics, and, the commercial production of fuelwood and charcoal in many countries is done illegally, making the acquisition of reliable statics difficult (UNECE/FAO, 2012a)

We also can note that the urbanization has a profound impact on human living and production patterns. It has transformed society's economic structure and lifestyle and, as a result, increased the demand for fossil fuels (Mahlia et al., 2003, Lam, 2000)

\subsection{Forest Degradation}

Today, the forest area is almost reduced to a few shreds of secondary forests, isolated in a succession of plantations (village or industrial) and fallow land. Forest cover amounted to 6.38 million hectares composed of 4.2 million hectares of forests classified heavily degraded (about 13\% of the country), 168,000 hectares of forest plantations and 2 million hectares protected areas. Deforestation has slowed over the past ten years but still remains well above the possibilities of regeneration of the natural forest. It is projected that, at current rates of deforestation, Côte d'Ivoire would have lost $83 \%$ of its virgin forest (SODEFOR, 2013) (see Figure 2). In addition, wood covers part of household energy needs. The domestic use of wood fuels increases with population growth and is a major cause of deforestation, especially in the savannah and in the vicinity of urban centers. 


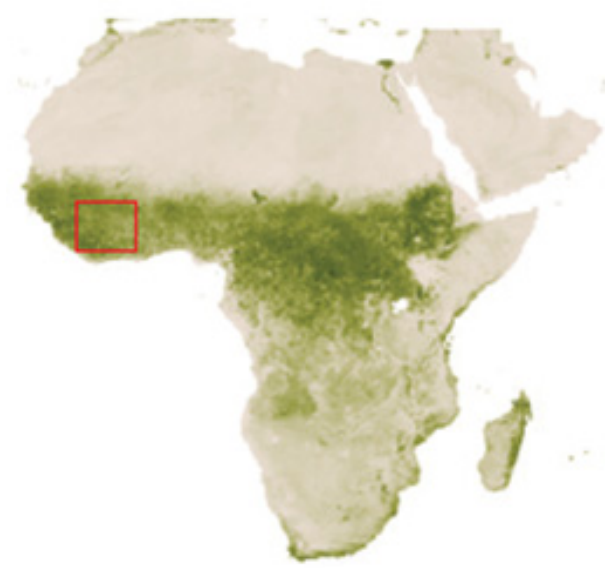

1981

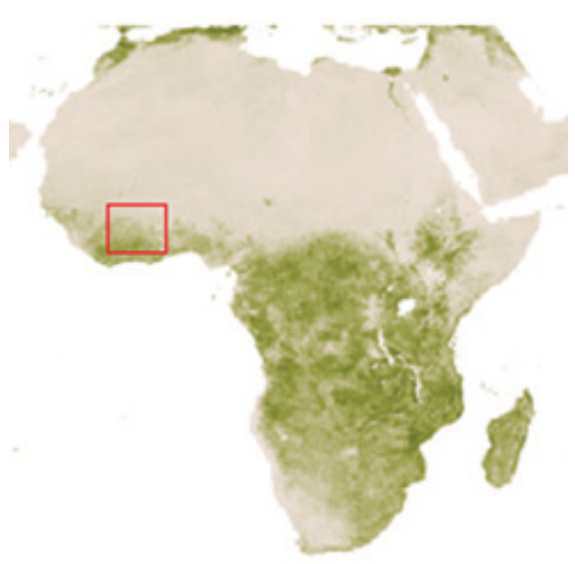

201

Figure 2. Forest cover of Cote d'Ivoire 1981-2014 (Source national oceanic and atmospheric administration)

Charcoal production has been increasing in the last 10 years, rising by $22 \%$ from 400,850 tons in 2003 to 488,128 tons in 2012 , in order to meet the demands of a growing, and increasingly urbanized, population. The production of wood fuel has also been increasing, although at a slower rate over the last ten years, from $8,699,979 \mathrm{~m}^{3}$ to $9,034,617 \mathrm{~m}^{3}$, almost a $4 \%$ rise. Charcoal is typically a fuel used in urban areas as it is seen as having fewer of the negative side effects of cooking with wood (i.e. dangerous, smoky) while being more cost-efficient than petroleum products (Girard, 2002). The increasing urbanization rate an average increase of 1.49 percent per year (World Bank, 2014) may help to explain why charcoal production is increasing at a far faster rate than wood fuel production.

\section{Methodology}

\subsection{Sample Selection}

The study design consisted of two stages. The first stage is on charcoal and fuelwood consumption and the second stage is based on environmental impacts. In our research we selected our sample from shantytown of the economic capital (Abidjan). The three recarious areas are Kramakoupe, Yaossei and Mossikro. So, 150 questionnaires have been distributed, 100 questionnaires for families, and 50 questionnaires for producers /distributors of charcoal.. In order to collection data, after getting permission, only 137 households and 28 producers and distributors accepted to participate with the overall response rate of $82.5 \%$. Also, Surveys were conducted with people who indicated that they produce and sell fuelwood or charcoal as one of their activities.

\subsection{Measures}

Qualitative approach stress the socially constructed nature of reality where the researcher makes knowledge claims that are based on constructivist perspective (Silverman, 2005). In view of the choice of qualitative approach, it is important to identify the exact methods of sourcing data and how relevant those methods are to the research problem (Rossouw, 2003; Silverman, 2005). Methods of sourcing data in a qualitative study include amongst others sampling, interviews, questionnaires and observations (Flick, 2002; Hay, 2000). Quantitative approach was useful in data presentation.

A socio economic study was conducted on some point. Age and household size was measured with a 5-point scale. Marital status was coded as a binary variable $(0=$ married and $1=$ unmarried $)$. For the knowledge of the disadvantages associated with the production and consumption of charcoal $(0=$ no and $1=y e s)$. And finally fuel choice between charcoal and fuwlwood for cook.

\section{Findings and Discussion}

\subsection{Energy Household Consumption for Cooking}

Household characteristics such as gender of heads, employment profile and size of households had been considered as important variables to determine between the amount of charcoal and fuelwood ,the most widely used energy for cooking in the household. 


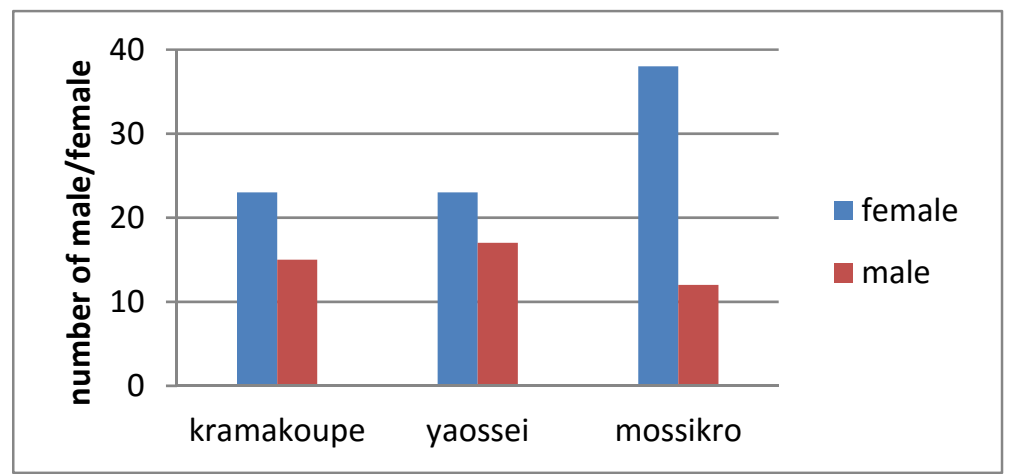

Figure 3. Gender of heads households

From the total participants, as we can see from graph 1, 67.88\% were female headed Households which were the highest for Mossikro followed by Kramakoupe.

\subsection{Age Structure of the Heads of Households}

From the "adults" interviewed, none was under the age of 20. Age group between 20 to 29 years had the least number of respondents of $12 \%$. Respondents in the age group between 30 to 39 years were $29 \%$. The 40 to 49 years category had the largest number of $37 \%$ respondents, while the 50 years and above had 12 respondents (see Figure $4 \mathrm{a}$ and $4 \mathrm{~b}$ below).

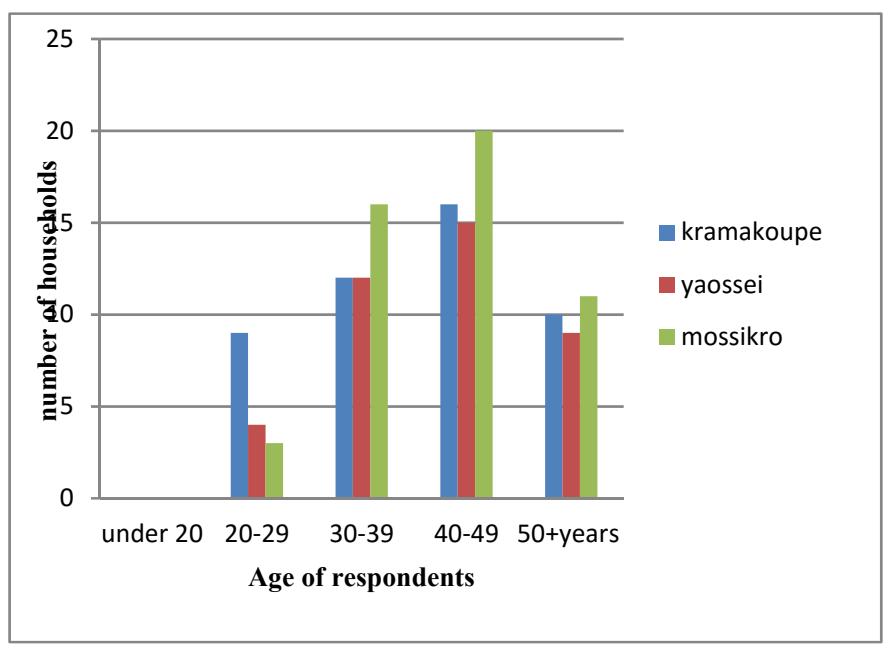

Figure 4a. Age distribution of the households by cities

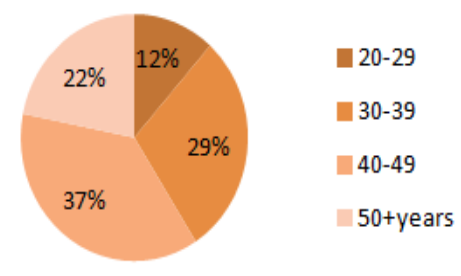

Figure $4 \mathrm{~b}$. global age distribution

\subsection{Employment Profile of the Respondents}

Of the 137 respondents that were interviewed, $11 \%$ had formal employment, $34 \%$ were informally employed while the remaining $55 \%$ were not employed (see Figure 5 below). 

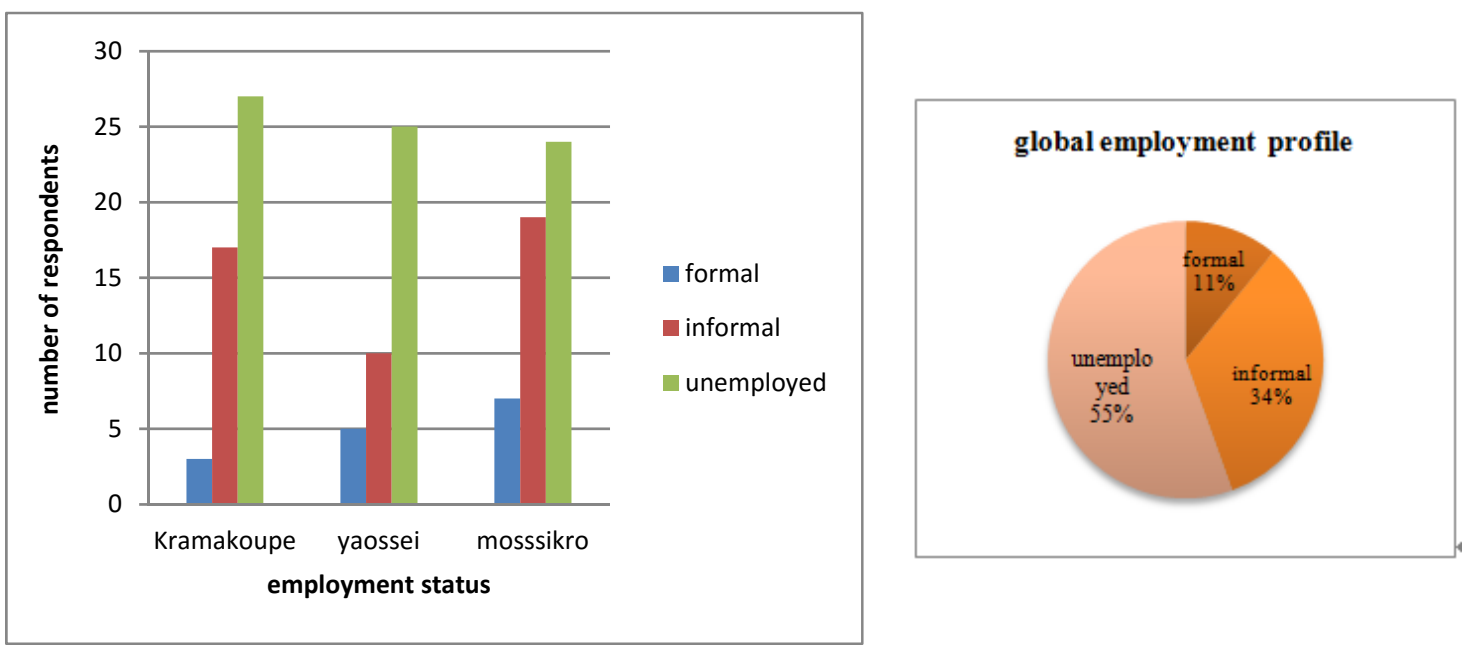

Figure 5. Employment profile of the respondents

All areas have a high rate of unemployment, with firstly Kramakoupe, followed by Yaossei

\subsection{Household Size}

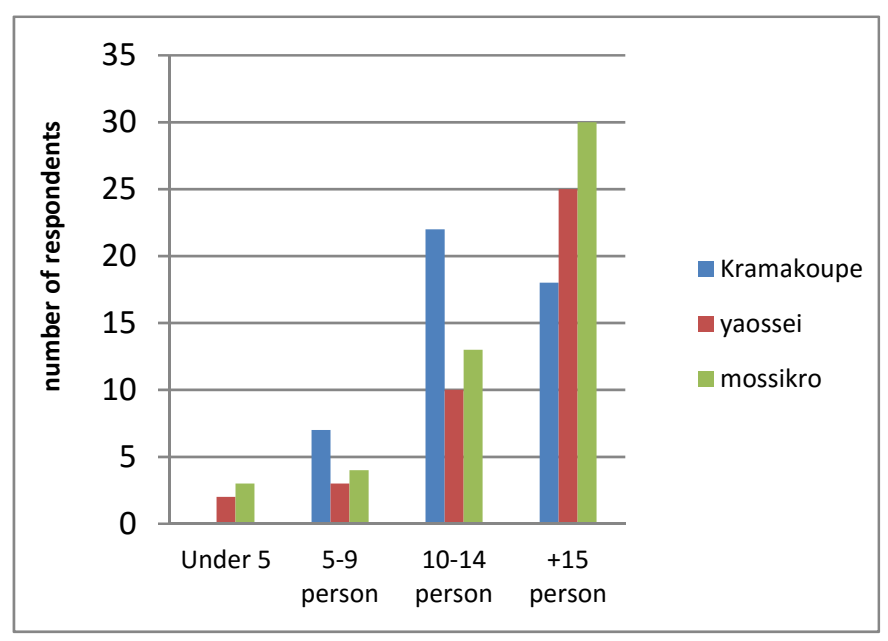

\section{Global household size}

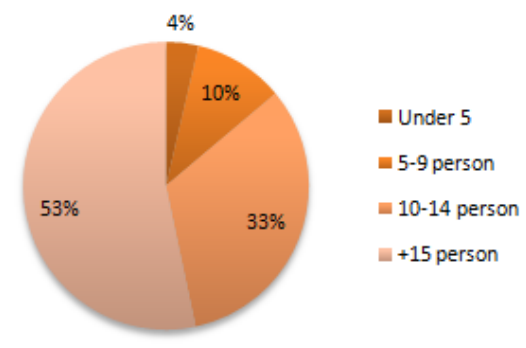

Figure 6. household size profile of respondents

\subsection{Energy Consumption Household}

We noted that the three areas consume high rates of charcoal and fuelwood. But the fuelwood is the most used fuel in households with 33\% . But, in area of mossikro there are more woodfuel consumers with $40 \%$. Households that use both fuels (Charcoal+ fuelwood) are 31\% with a high rate of $36.7 \%$ in the Kramakoupe. Only $14 \%$ of households use other fuels such as butane gas.

Moreover, domestic cooking, firewood and charcoal are source of income for households in some activities

- Traditional bakeries,

- The fish-smoking ovens,

-Sales food 


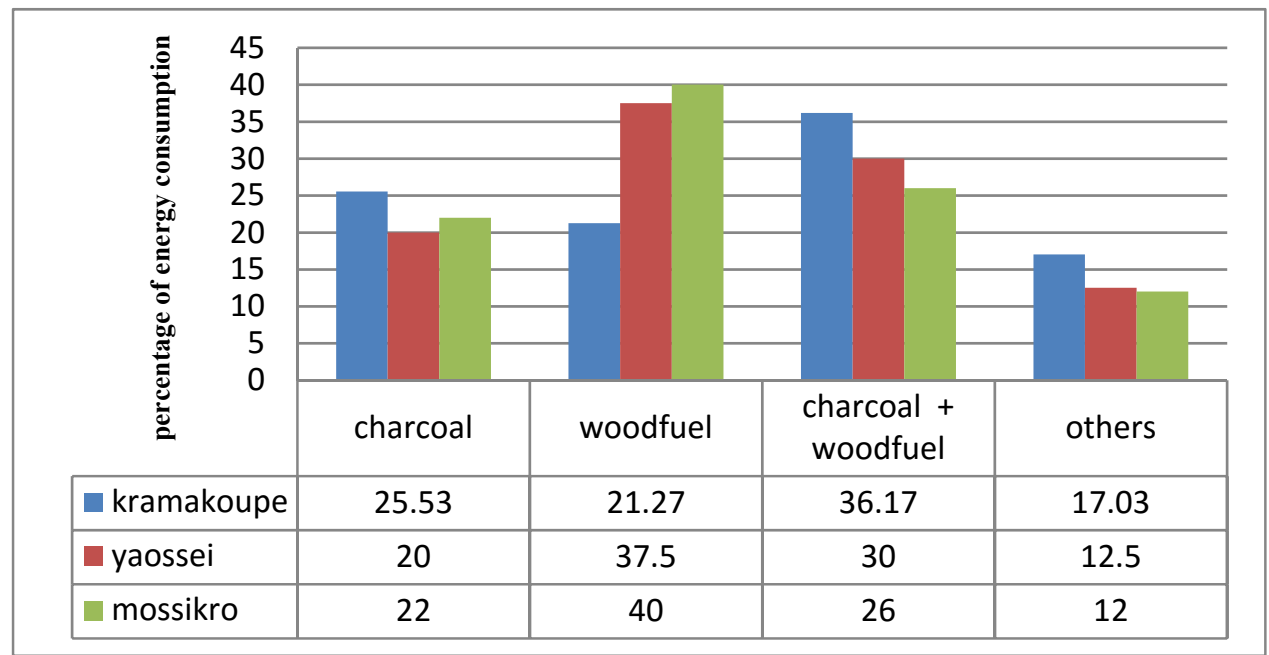

global energy consumption by
household

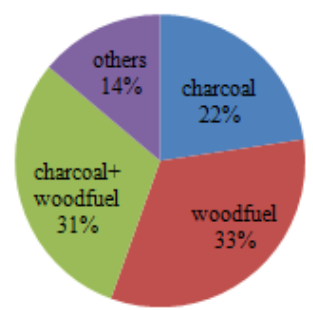

Figure 7. energy consumption profile of respondents

Table 1. activities using fuels

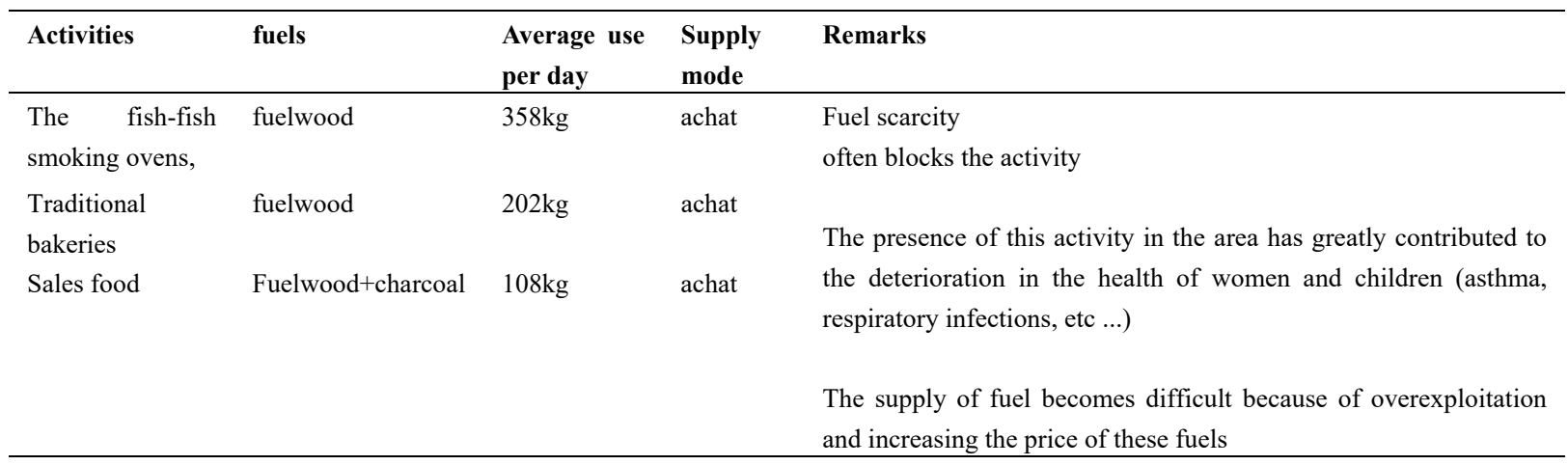

\subsection{Charcoal and Fuelwood Supply Chain}

After interviews with vendors and charcoalers and firewood producers we can note that Wood harvesting is done in rural areas. In general, rural population use fallen wood, dead branches and twigs picked off from the ground. Some of the wood harvesting is used to make charcoal and the other part is used directly as fuelwood. Fuelwood and charcoal are transported surrounding cities to Abidjan (Figure 8) 


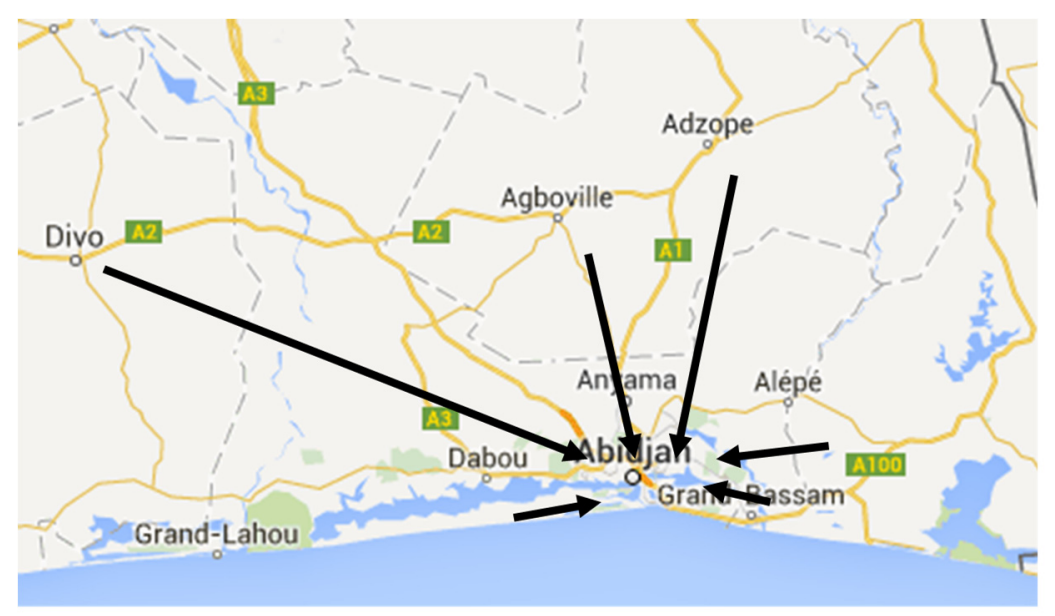

Figure 8. map of charcoal and fuelwood transportation

The traders that indicated that they buy their wood from transporters normally place an order to the transporters for a certain amount of wood and this is delivered in to their vending site.

They then sell the wood in small bundles in makeshift structures or open air spaces minimizing their operation expenses. A simplified map of the fuelwood value chain in Kenya is shown in Figure 9

The fuelwood sector is quite complex and not linearly organized as presented in the map above. The price of wood varies greatly depending on the buyer and the intended market. The charcoal value chain though informal, is quite well established with a distinct production, transportation and retail line. However, as noted by several other researchers (Sepp and Mann, 2009, Mugo and Ong, 2006, ESDA, 2005 and Kituyi, 2001), the value of wood used for charcoal production is not reflected in the value of the charcoal.

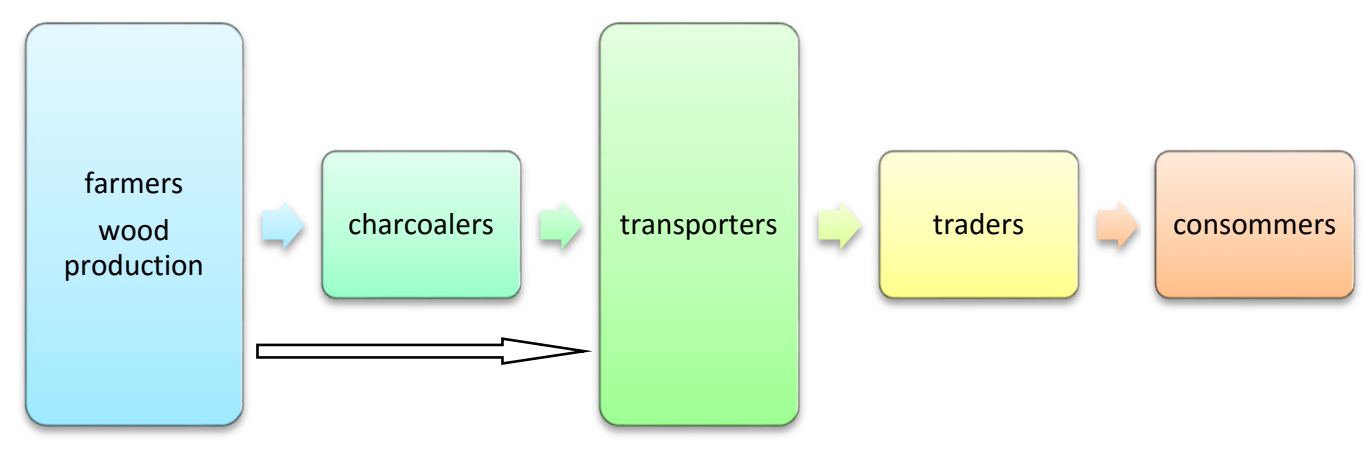

Figure 9. wooddfuel and charcoal supply chain in Cote d'Ivoire

\subsection{Charcoal Production}

\subsubsection{Charcoal Kiln Process}

In Africa, the main type of charcoal production carried out in the rural areas is the traditional kiln production. The ideal season for making charcoal is the dry season. The use of dry woods was better to the manufacturer, because it is essential to reduce the amount of water content in the wood in order to minimize the amount of heat energy that would be needed during the drying process; , so woods was are cut days prior to charging the kiln . Before charging the kiln, the dug pit is covered with a layer of leaves. This layer was put between soil and wood as it had the importance of collecting charcoal from clear ground. Those openings could be judiciously opened and closed and new ones could be made to control the introduction of air (A Zidago and Zhangqi, 2014). The wood to be carbonized is then stacked in a pile and covered with a layer of leaves and earth. This is needed during carbonization process because the soil takes the heat and continues to burn the charcoal. The charcoal then burns completely and produces a high amount ash and carbon content in the air. (see Figure 10) 


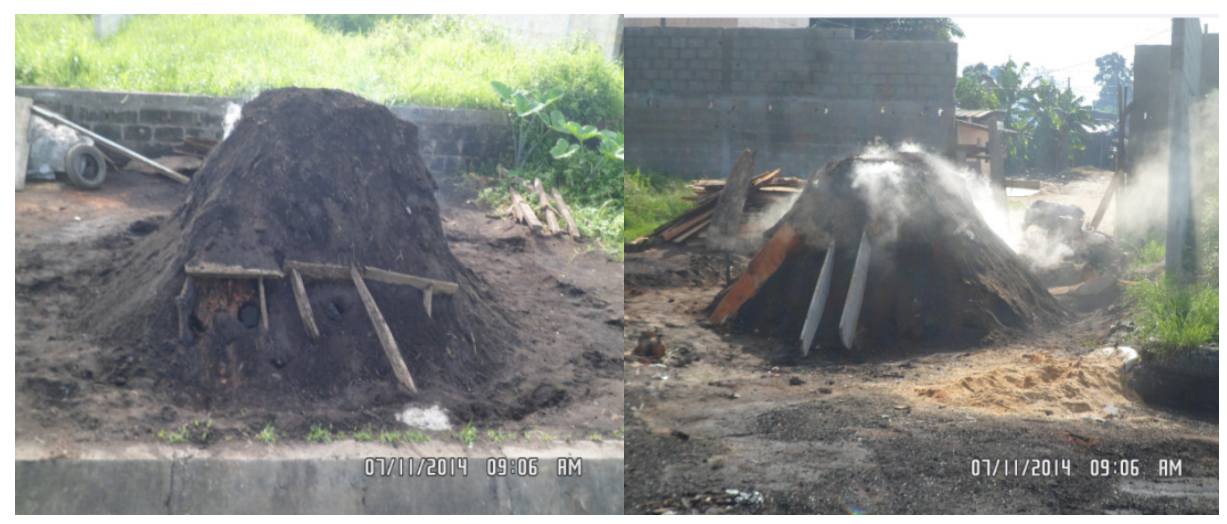

Figure 10. charcoal production kiln Consumption of traditional fuels and its side effects

When firewood is burned inside the home; toxic fumes fill the lungs of children and threaten the health of the entire family .According to World Health Organization, 1.5 million people die every year from respiratory diseases related to smoke inhalation; most of them women and children.

The use of biomass fuels like firewood for cooking or heating leads to high levels of indoor air pollution; especially when burned on traditional stoves or open fires indoors. Use of unsafe or inappropriate fuel sources (e.g., plastic; waste) can also lead diseases.

Women spend an average of three to seven hours per day near stove preparing food. Young children are often carried on their mothers back or kept close to the warm hearth. Consequently, infants spend many hours breathing indoor smoke during their first year of life when their first year of life when their still-developing lungs make them particularly vulnerable to hazardous pollutants. Fifty-six percent of all indoor air pollution attributable deaths occur in children under five years of age (WHO).

The inefficient burning of solid fuels on an open fire or traditional stove indoors creates a dangerous cocktail of hundreds of pollutants, primarily carbon monoxide and small particles, but also nitrogen oxides, benzene, butadiene, formaldehyde, polyaromatic hydrocarbons and many other health-damaging chemicals.

Day in day out, and for hours at a time, women and their small children breathe in amounts of smoke equivalent to consuming two packs of cigarettes per day.(WHO, 2006), In Cote d'Ivoire, $90 \%$ of Ivorian households use charcoal. Charcoal is produced via pyrolysis, or thermal degradation, of biomass. This partial combustion, in an oxygen-poor environment, results in formation of products of incomplete combustion (PICs), such as $\mathrm{CH} 4, \mathrm{CO}$, alkanes, alkenes, oxygenated compounds and particulate matter. In ideal biomass combustion only $\mathrm{CO} 2$ and $\mathrm{H} 2 \mathrm{O}$ would be formed; in practice, however, various amounts of PICs are produced, depending upon operating conditions. Lacaux, et al (1994), has related that in his study on charcoal measure the quantity of CO2 and trace gas emissions from a charcoal kiln in the field. These data are from one burn cycle for a traditional mound kiln in West Africa. As expected, the charcoal kiln emission ratios of $\mathrm{CO}, \mathrm{CH} 4, \mathrm{NMHC}$, and $\mathrm{NH} 3$ to $\mathrm{CO} 2$ are larger than those from savanna burning. Because $\mathrm{CO}, \mathrm{CH} 4, \mathrm{NMHC}$ have much higher global warming potentials than $\mathrm{CO} 2$, emissions from charcoal production may pose a serious peril to the upper atmosphere. Even on a per $\mathrm{kg}$ of wood basis, the global warming impact of biomass pyrolysis for charcoal may be greater than that of biomass burning, and should be quantified. Cote d'Ivoire, as in many other African countries, cooking is done only by women. Several studies in different countries have shown that all women who use wood or charcoal for cooking are exposed to dangers seriously.

The quantity of each pollutant released is dependent on combustion conditions such as energy density, combustion temperature and air flow, and pollutant emission rates which vary with time and stove geometry (Ballard-Tremeer and Jawurek, 1999; Ezzati et al. 2000; Ezzati .and Kammen, 2002).

\subsection{Discussions and Conclusions}

This paper examined household based energy consumption behavior. This was conducted by investigating, the effect of various underlying socio-economic drivers and energy substitution choice between charcoal and fuelwood. The results support greater policy efforts to resolve household energy access problem to mitigate related environmental impacts and societal problems. The finding of this paper has many important policy insights for country's energy policy. 
First, hypothesis that woodfuel commercialization contributes to household diversification. Around Mossikro, fuelwood consumption. Fuelwood provides the most substantial, single contribution to household income for producers (on average $22 \%$ for charcoal, $40 \%$ fuelwood and $26 \%$ charcoal + fuelwood). Around Kramakoupe, although smaller, charcoal still forms a considerable proportion $25.53 \%$ and $36.17 \%$ charcoal + fuelwood of household income.

Second, result from this analysis indicated no evidence of fuel substitution between fuelwood and agricultural fuels but fuel substitution between fuelwood and charcoal. There are many plausible explanations for the substitution effect. The choice of these fuels is due to their accessibility and affordable price for those households living in these environments. Poverty is also the basis of this choice. Socioeconomic status shows that the head of these families are women. So there are 55\% unemployed and $34 \%$ who work in the informal sector. Head of households who work in informal sector are also linked to charcoal and fuelwood to meet the needs of their families.

Third, charcoal and fuelwood consumption has therefore a socio economic impact. Most households have knowledge about the harmful effects of the charcoal and fuelwood consumption on health but households prefer the use of these fuels because these fuels are more affordable. Charcoal production technology is very difficult and bad for health (burns, chronic cough) but since this activity is an income source the adverse health risks are ignored.The negative effect of fuelwood scarcity on household fuelwood and total biomass energy use has important implication for government policies regarding afforestation and sustainable forest management that offers important option for improving household livelihoods. It suggests that greater access to "clean energy" such as LPG is expected to enhance household welfare and productivity. Also, LPG is very necessary to reduce indoor smoke. Certainly, it is recommended the use of LPG for the reduction of pollutants but use two fossils fuels such as (charcoal + LPG) by households will improve of economic and environmental situation of families.

\section{References}

Ballard-Tremeer, G., \& Mathee, A. (2000). Review of interventions to reduce the exposure of women and young children to indoor air pollution in developing countries. WHO/USAID consultation on Indoor Air Pollution and Health May, 3-4.

Clancy, L., Goodman, P., Sinclair, H., \& Dockery, D. W. (2002). Effect of air-pollution control on death rates in Dublin, Ireland: an intervention study. The lancet, 360(9341), 1210-1214.

Ezzati, M., \& Kammen, D. M. (2001). Indoor air pollution from biomass combustion and acute respiratory infections in Kenya: an exposure-response study. The Lancet, 358(9282), 619-624.

Ezzati, M., Vander Hoorn, S., Lopez, A. D., Danaei, G., Rodgers, A., Mathers, C. D., \& Murray, C. J. (2006). Comparative quantification of mortality and burden of disease attributable to selected risk factors. Global burden of disease and risk factors, 2, 241-396.

Flick, U. (2002). An introduction to qualitative research. London: Sage.

Girard, P. (2002). Charcoal production and use in Africa: what future?. Unasylva, 53(4), 30-35.

Hay, I. (2000). Qualitative Research Methods in Human Geography. Oxford: Oxford University Press.

International Energy Agency (IEA). (2014). Key World Energy Statistics (2014 ed.). Paris: IEA.

Kituyi, E. (2002). Towards Sustainable Charcoal Production and Use: a Systems Approach. In Proceedings of a Regional Workshop on Wood fuel Policy and Legislation in Eastern and Southern Africa. Ed, Mugo, F., RELMA Nairobi (pp. 46-62).

Lacaux, J. P., Brocard, D., Lacaux, C., Delmas, R., Brou, A., Yoboué, V., \& Koffi, M. (1994). Traditional charcoal making: an important source of atmospheric pollution in the African tropics. Atmospheric research, $35(1), 71-76$.

Lam, J. C. (2000). Residential sector air conditioning loads and electricity use in Hong Kong. Energy Conversion and Management, 41(16), 1757-1768.

Mahlia, T. M. I., Masjuki, H. H., Saidur, R., Choudhury, I. A., \& NoorLeha, A. R. (2003). Projected electricity savings from implementing minimum energy efficiency standard for household refrigerators in Malaysia. Energy, 28(7), 751-754.

Ministry of Housing, the living and the environment. (1997). Profil environnemental de la zone côtière, Abidjan.

Mugo, F., \& Ong, C. (2006). Lessons of eastern Africa's unsustainable charcoal trade. ICRAF Working Paper no. 20. Nairobi, Kenya. World Agroforestry Centre. 
Rossouw, D. (2003). Intellectual Tools (2nd ed.). van Schaik Publishers, Pretoria.

Sepp S., \& Mann, N. O. (n.d.). Analysis of charcoal value chain - general considerations. GTZ Germany.

Silverman, D. (2005). Qualitative Research Practice. Sage, London.

SODEFOR. (2013). Societe pour le Developpement Forestier. Presentation (in French). Retrieved May 6, 2014, from $\mathrm{http}: / / \mathrm{www}$.sodefor.ci/index.php/fr/presentation-27

UNECE/FAO. (2012). UNECE/FAO Introduction to energy statistics: they role in policy and decision makinginternational perspective United Nations Economic Commission for Europe (UNECE)/Food and Agriculture Organization of the United Nations (FAO) Joint Wood Energy Enquiry (2012 WHO, World Health Organization, report 2010.

Zidago, A. P., \& Wu, Z. (2015). Analysis of Fuelwood and Charcoal Sector in Cote d'Ivoire. International Journal of Science and Technology, 4(1).

\section{Copyrights}

Copyright for this article is retained by the author(s), with first publication rights granted to the journal.

This is an open-access article distributed under the terms and conditions of the Creative Commons Attribution license (http://creativecommons.org/licenses/by/4.0/). 